\title{
A fome de Ferreira Gullar
}

Roberto Sarmento Lima ${ }^{1}$

\section{Resumo}

A presença, na literatura brasileira, da metáfora do alimento e especialmente de frutas, desde o período colonial aos nossos dias, serve para abrir uma discussão sobre os rumos e hábitos verificados no desenvolvimento da sociedade, a que não ficam alheios, na atualidade, poetas como Ferreira Gullar, que também se serviu criticamente dos mesmos motivos.

Palavras-chave: açúcar; frutas; sociedade brasileira; crítica social; Ferreira Gullar

\section{Résumé}

Dans la littérature brésilienne, depuis la période de la colonisation jusqu'à nos jours, la présence de la métaphore de la nourriture, et, tout spécialement, celle des fruits, nous invite à ouvrir une discussion concernant les voies et les habitudes rencontrées tout au cours du développement de notre société. Les écrivains n'y sont pas indifférents.

${ }^{1}$ Professor Associado 4 e doutor em Literatura Brasileira, lotado na Faculdade de Letras da Universidade Federal de Alagoas. É autor de O pai fracassado-revisão crítica e modernidade em Vidas secas, de Graciliano Ramos. Tese de doutoramento (Ufal), publicada em 2015 pela OmniScriptum, Novas Edições Acadêmicas ( Särbrucken, Alemanha).E-mail: sarmentorob@uol.com.br 
Tel est le cas du poète Ferreira Gullar (1930-2016), qui a su utiliser ces mêmes motifs de façon critique.

Mots-clés: sucre ; fruits ; société brésilienne ; critique sociale ; Ferreira Gullar

Nãohátrabalhos mais doces queo das vossas oficinas, mas toda essa doçura para quemé? Sois como abelhas, de que disse o poeta. [...] As abelhas fabricam o mel, sim, mas não para si.

Padre Antônio Vieira, Sermão XIV do Rosário pregado na Bahia à irmandade dos pretos de um engenho em dia de S. João Evangelista, no ano de 1633.

\section{Introduzindo a questão: negociação comercial no poema}

"Você tem fome de quê?", pergunta a banda de rock Titãs em um verso do poema "Comida", assinado por Arnaldo Antunes, faixa do disco Jesus não tem dentes no país dos banguelas, de 1987. Antes dele, bem antes mesmo, no início do século XVII, o capitão-mor baiano Manuel Botelho de Oliveira, na pele de um agente da Metrópole, a serviço do rei, parece responder a uma pergunta desse tipo, oferecendo à vista de todos os que comem e precisam comer uma lista copiosa de frutas e legumes, que faz desfilar ao longo da silva “ÀIlha de Maré”. Instala-se, na memória cultural brasileira, a presença das frutas e do açúcar:

As canas fertilmente se produzem

E a tão breve discurso se reduzem,

Que, porque crescem muito,

Em doze meses lhe sazona o fruto 
Percebe-se que o poeta se inflama na menção às qualidades de cajus, ananases, laranjas e de improváveis maçãs, sem esquecer a fartura de "polvos radiantes" e de "lagostins flamantes" que fazem as delícias do Novo Mundo. Nisso é bem acompanhado pelos cronistas e historiadores da época, como o cristão-novo português Ambrósio Fernandes Brandão e o baiano Sebastião da Rocha Pita, o que prova não ser tal elogio apanágio exclusivo da lírica, mas advém comumente das circunstâncias de quem então escrevia, tomados todos pelanecessidade de desbravar, pela palavra, sempre muito positivamente, a realidade nova que se descortinava então. Nesse afã entusiasta, Botelho, assim como os demais, fez vista grossa para a paisagem rude e mais seca do interior da Bahia, nem sempre verdejante, nem sempre de climas amenos.

De várias cores são os cajus belos, Uns são vermelhos, outros amarelos.

E como vários são nas várias cores,

Também se mostram vários nos sabores

O estímulo à formação da cultura açucarada do Brasil, de que as frutas são, de ordinário, os seres naturais mais lembrados, no verso ou na prosa, integra as motivações desse "comércio de doçura" (SCHWARCZ; STARLING, 2015, p. 50) que tanto encantava os europeus e que, tempo vai, tempo vem, deixa ao menos nos brasileiros, até hoje, a lembrança do frescor do alimento, sem, contudo, as marcas da sua idealização. A aparência exuberante e vivaz de frutas aprazíveis é, desse modo, a face natural - e certamente a mais poética - daquilo que se oculta durante a produção do açúcar, a qual, voltada exclusivamente para o mercado de fora naqueles inícios da colonização portuguesa, não se inclinava, pois, a satisfazer, preferencialmente, o consumo interno, que ficava à deriva.

A política colonizadora, desde então, investia na ocupação das terras para apenas incentivar e realizar "a expansão comercial da Europa", sob pressão político-econômica daquele continente, em crescimento 
desde o século XI. Assim como navegar é preciso, povoar as novas terras descobertas era também preciso, porque "prevalecia o princípio de que espanhóis e portugueses não tinham direito senão àquelas terras que houvessem efetivamente ocupado"(FURTADO, 1974, p. 6). Desdeentão, o açúcar, vindo da região do Mediterrâneo e distribuído pela Holanda, era o produto mais competitivo; restava a Portugal entrar nesse circuito com o pretexto, não necessariamente artificial, de ratificar seu domínio na nova colônia e protegê-la da invasão de estrangeiros, preservando-a para si. $\mathrm{Na}$ prática, no encalço de repetir a façanha da produção prestigiosa do açúcar naquele momento histórico, teve a Colônia de estabelecer, forçosamente, uma atividade econômica de recorte reprodutivo, especular, porquanto esta, diz ainda Furtado, funcionando como "parte integrante" do comércio europeu (tanto na sua produção quanto na sua distribuição, fazendo um círculo completo sem nenhuma originalidade), ${ }^{2}$ revelaria logo seu interesse para o processo colonizador. Do contrário, a própria colonização não mostraria sua real importância; e, em caso de tal política não obter êxito, "dificilmente Portugal teria perdurado como grande potência colonial na América" (FURTADO, 1974, p. 8), porque a Colônia, como tal, vista como "terras de escassa ou nenhuma utilização econômica" (idem, p. 7), pareceria totalmente imprestável ou enfraquecida.

Não deve ter sido à toa que - no plano simbólico, por provável homologia com o plano político-econômico, algo que se entrevê ora

\footnotetext{
${ }^{2} \mathrm{O}$ circuito era este: o Brasil implantou, pela ação colonizadora portuguesa, a produção do açúcar, desde 1535, em Pernambuco, com perspectiva inteiramente voltada para o mercado externo; e, tal qual na Europa, recorreu-se à intermediação da Holanda, que já distribuía e redistribuía o produto por lá. Assim, a empresa econômica lusa apenas valorizou o comércio e o consumo no Velho Mundo, sem que se tivesse pensado que a ação poderia ser revertida em favor da colônia, visando ao seu desenvolvimento. Era, na época, um processo de globalização existente, conforme as possibilidades do momento, o que forçou a tônica de ignorar fronteiras e restrições geográficas e econômicas desse mundo comercial. Aliás, nesse mesmo sentido, como se fronteiras geográficas fossem coisa de somenos importância naquele recorte temporal histórico, os portugueses que se instalaram no Brasil apenas o fizeram sem muito estudo e por tempo limitado, já que o objetivo era voltar para casa e levar alguma riqueza no bolso.
} 
de modo surdo, ora explosivo - o açúcar também figurasse como uma preocupação, a ponto de corporificar-se em tema literário. As frutas do poema de Botelho exemplificam e metaforizam um correspondente objetivo econômico da produção do açúcar, ${ }^{3}$ enquanto seu desfile e amontoamento pelos versos - aparentemente à revelia das injunções históricas - parecem ser tão somente a declaração otimista de um motivo exótico, digno apenas de ser exaltado pela diferença que a paisagem tropical entretém, por comparação, com a natureza europeia. Ou, por outro lado, se não se quiser descer a fundo em uma pesquisa de base histórica e econômica, isso poderá ser explicado em favor de uma moda que, de tendência europeia, típica daquela época, provém da prática de pintura de naturezas-mortas. ${ }^{4}$

Dado o contexto colonial que nos diz respeito mais de perto, a recorrência das frutas toma aqui, porém, nova direção: muito suavemente, sob efeitos da euforia da menção à natureza que se instala em todos os versos dessa silva, denuncia-se subliminarmente o alheamento da presença do homem - não parece que se encontra deserta a Ilha de Maré? selvática, quase em estado edênico, ignorada por seus habitantes, entregue ao deusdará? -, modo com que se apaga do horizonte qualquer referência à realidade dura imposta aos que vivem na terra. Poesia revela, mas também esconde, e nenhum discurso o faz melhor. No caso, esconde o nativo, o escravo, o senhor de engenho, o colonizador, a mulher, o menino, o cachorro, o papagaio, tudo que pudesse servir de alusão, por menor que fosse, à vida

${ }^{3}$ Como afirmam Schwarcz e Starling (2015, p. 50), “o açúcar não pode ser entendido somente como um produto. Ele é [...] produtor de códigos, costumes e hábitos" (grifo das autoras). Se é assim no campo da investigação sociológica e historiográfica, oque dizer então da linguagem literária, que manipula conscientemente efeitos de sentido, à custa da utilização de efeitos retóricos e artifícios de construção?

${ }^{4}$ Esta é uma hipótese de leitura possível, nada desprezível, mas não é a que eu endosso neste ensaio. Creio que possa até ser complementar aos meus objetivos de análise, mas, querendo sair dos limites que circunscrevem o mundo artístico, prefiro aventurarme em uma pesquisa de estofo histórico, a meu ver, mais produtiva e também mais significativa. Kothe levanta essa possibilidade referindo-se à poesia de Manuel Botelho (1997, p. 283), sem, no entanto, demonstrar muita convicção a esse respeito. 
colonial brasileira e, num nível mais elevado de consciência histórica (coisa que faria Botelho tremer nas bases), às estratégias de recrutamento de mão de obra, necessária ao expansionismo econômico. Como numa espécie de redoma que envolve um segredo - por exemplo, a ocultação da áspera realidade do trabalho e seus corolários, principalmente a escravização do índio -, a ilha metamorfoseia-se em uma concha fechada, que, embora "pouco apetecida", guarda uma "pérola formosa":

Vista por fora é pouco apetecida,

Porque aos olhos por feia é parecida;

$[\ldots]$

É como a concha tosca e deslustrosa,

Que dentro cria a pérola formosa. (grifos meus)

Carente de beleza externa, a ilha só é boa por dentro ("Porém dentro habitada / é muito bela, muito desejada"), poderia fazer pensar o poeta. Mas a imagem da concha que guarda e esconde, e, ainda por cima, sendo ela "pouco apetecida", se "vista por fora", tem a utilidade de desviar o olhar de cobiça de aventureiros. Pelas convenções cultistas, porém, o poema deveria tornar a ilha, por fora também, um primor. O que faz comer com os olhos prepara a hora de comer com o estômago, diz a regra geral. Imprimir feição nova e radiante a um objeto, entendida assim a concepção de poesia como um composto de forma e fundo, é missão do poeta, que termina por optar por noções barateadas como formato ou fôrma. ${ }^{5} \mathrm{E}$, ao menos naquele momento, para o poema atingir o nível de beleza pretendido, bastaria falar da fartura dos víveres, dos produtos naturais, do seu verdor, das suas águas... Razão por que "a concha tosca e deslustrosa", por si só uma metáfora - afinal, trata-se de umaconcha, mesmo que mal cuidada e sem brilho -, serve para representar a ilha em

\footnotetext{
${ }^{5}$ A distinção entre forma e fôrma, mantido o acento circunflexo para diferenciar uma palavra da outra, dentro do recente acordo ortográfico da língua portuguesa, de 2009, é aqui bastante elucidativa.
} 
sua aparência externa. Confere-se, por fim, toque de beleza ao que lá não tem essa graça toda. Entretanto, assim recriado o invólucro, fica atestado que aquilo que ele guarda é o que pode haver de melhor no poema ("a pérola formosa"), ${ }^{6}$ sendo esse, pois, o mérito da concha. O que se vê pelo lado externo, por fora, desse modo, repete, reduplica, graças à metáfora utilizada, o que está dentro, aquilo que não se vê logo.

\section{Imitação dos motivos: econômicos e literários}

Começaria, aí, nossa vocação e tendência-a partir da sugestão dada pelas frutas e pelo universo da produção do açúcar, sob a administração da poética barroquizante - para a imitação do centro, o chamado mundo europeu, que nos serviria de exemplo? O português Ambrósio Fernandes Brandão, que viveu na Colônia entre 1583 e 1618 (curiosamente, era senhor de engenho), ajuda a compor esse mosaico de relações entre poesia, história e vida social, em seus Diálogos das grandezas do Brasil (1618) pela boca da personagem Brandônio, espécie de voz ficcional do próprio autor, como já sugeriu Capistrano de Abreu. A imitação, que nos deu e daria coerência sistêmica e alguma relevância no mundo dos negócios, se desenvolveria, entre nós, emcascata, desde os "primeiros povoadores" aos "demais", constituindo, por essa base, uma espécie de cultura especular:

BRANDÔNIO - [...] Nesse nosso Brasil os seus primeiros povoadores deram em lavrar açúcares; pois que muito é que os demais os fossem imitando, conforme o costume geral do mundo, que tenho apontado? (BRANDÃO, 2010, p. 54) (grifos meus)

\footnotetext{
${ }^{6}$ Sugiro que se deva ler o poema "Guardar", de Antonio Cicero, para compreender melhor essa ideia estética. Esse poema integra a coletânea Guardar: poemas escolhidos, publicado pela editora Record, no Rio de Janeiro, em 1996. O poema abre o livro, na página 11.
} 
Assim é que, nesse movimento, o açúcar, o doce, as frutas e tudo que tenha o seu rastro têm, em nosso imaginário, um papel fundador, a atingir a lírica em seu coração, até o presente. O que, inicialmente, se deu por claras motivações econômicas, fazendo cristalizar essa memória do açúcar - afinal, como dá a entender Botelho, a matriz europeia domina não só o negócio do comércio bem como institui, agora por via simbólica, o negócio do poema -,

As frutas quase todas nomeadas

São ao Brasil de Europa transladadas (grifo meu)

termina por ser um dado definidor dessa cultura colonizada. O transplante e acomodação, entre nós, de valores alienígenas é, por esse viés de interpretação, inevitável, embora só, ou principalmente, aqui - "por mais façanhas" de que seja dotada a Colônia, com essa natureza prodigiosa, digna de ser cantada em versos - as frutas se deem naturalmente tão bem:

Porque tenha o Brasil por mais façanhas

Além das próprias frutas, as entranhas. (os grifos são meus)

É a renovação do "em se plantando tudo dá" que se encontra na Carta de Pero Vaz de Caminha, aquele mesmo da frota de Cabral. Aos olhos dos portugueses só o negócio do açúcaréque pareceu vantajoso, ou possível, como diz Brandônio/Brandão a Alviano, seu interlocutor implicante, o qual the serve de contraponto. Fazendo um paralelo entre os colonizadores espanhóis, que se dedicaram preferencialmente à exploração de minas, e os seus patrícios, engolfados no litoral, destinados tão somente a fazer açúcar, Brandônio parece certo do que diz, apesar do estilo de concessões:

BRANDÔNIO - Não se pode tirar aos castelhanos serem bons conquistadores e descobridores; porque atravessaram conquistando, desde Cartagena e Chile 
e Rio da Prata, que é inumerável terra, pela qual foram achando quantidade grande de minas de ouro, prata, cobre, azougue [...] mas nem por isso se deve de atribuir aos nossos portugueses o nome de ruins conquistadores.

ALVIANO - Como não, se vemos que em tanto tempo que habitam neste Brasil, não se alargaram para o sertão para haverem de povoar nele dez léguas, contentando-se de, nas fraldas do mar, se ocuparem somente em fazer açúcares? (BRANDÃO, 2010, p. 52)

No caso específico aqui lembrado, as frutas doces e formosas "Ah! se a Holanda os gozara", nota Botelho, com súbito tino comercial - dão corpo à urgente necessidade de povoamento e de desenvolvimento dessa atividade comercial na terra descoberta. Sem tal perscrutação sociológica, o poeta baiano até que poderia ser considerado um poeta nativista (certamente essa é uma leitura que o século XIX romântico fez dele). Mas a ideia é outra: bem ao avesso dessa interpretação, Manuel Botelho representava os interesses de Portugal na Colônia; ${ }^{7}$ não oferece obstáculos, aliás, tal dedução, dada a clareza da expressão presente nos seus versos, detectando-se de que lugar ele instaura sua fala:

Falar de "esmeraldas de Abril em seus verdores" como tendo desterrado "do Inverno os desfavores" contém explícita uma perspectiva europeia, nórdica, em que a primavera irrompe no mês de abril, e não em setembro, como no hemisfério Sul (KOTHE, 1997, p. 282$)^{8}$

\footnotetext{
${ }^{7}$ Remetoà leitura do capítulo "O verso e a versão", contidonolivro O cânone colonial, de Flávio Kothe (1997, p. 277-294).

${ }^{8}$ Do mesmo modo também — sem ser exatamente um mal, já que a norma medida pelo cânone internacional era então regra - isso se verifica nos versos cultistas de Gregório de Matos, que, lembrado sempre por seu espírito corrosivo e crítico na sátira (gênero que, por sinal, tambémé colaborador do sistema, porque visa à sacralizaçãode condutas sociais dominantes), faz parte, como não poderia deixar de ser, dessa mesma sintonia
} 
Nem tudo são flores, evidentemente. Nemperas e laranjas e maçãs. A imagem deletéria da produção do açúcar, nada doce, não escapou ao olhar crítico e atento de Antonil, em seu Cultura e opulência do Brasil, de 1711, numa descrição que, não fosse o gosto retórico vigente, poderia chegar a constranger:

Junto àcasa da moenda, quechamamcasa deengenho, segue-se a casa das fornalhas, bocas verdadeiramente tragadoras de mato, cárcere de fogo e fumo perpétuo e viva imagem dos vulcões, Vesúvios e Etnas e quase disse, do Purgatório ou do Inferno. Nem faltam perto destas fornalhas seus condenados, que são os escravos boubentos e os que têm corrimentos, obrigados a esta penosa assistência para purgarem com suor violento os humores gálicos de que têm cheios seus corpos. (apud RONCARI, 1995, p. 185-186)

Assim, no futuro sobretudo, como numa espécie de memória cultural e histórica, não faltaria quem, para temperar o idealismo da proposta inicial, pudesse enxergar fel no melaço e revelar-melhor e mais criticamente - nossas deficiências, que parecem sempre nos caracterizar na acidentada formação geral do país. Não raro, enfim, a poesia não deixa de denunciar a presença da violência que faz parte dessa primeira produção econômica (não seria tarefa, pois, apenas de historiadores), mas que insiste em ficar e radicar-se. É o que se vê no poema "O mapa", do poeta Fernando Fiúza, num passo a passo que fala por si só:

Há quem perceba no mapa geográfico de Alagoas

o formato de um revólver.

imitativa, revelando sua adequação ao código vigente e ao sentimento de prestígio estético, e, por vezes, sua submissão a estes: "E a vaidade, Fábio, nesta vida, / Rosa, que da manhã lisonjeada, / Púrpuras mil, com ambição dourada, / Airosa rompe, arrasta presumida./Éplantaque, deabrilfavorecida,/Pormares desoberbadesatada,/Florida galeota empavesada, / Sulca ufana, navega destemida." (o grifo é meu) 

O lado externo do cabo
é de esmeralda corrente
e um morno colar de areia;
o de dentro, também verde,
de canaviais e mangue,
lagoa, riachoe rio. (grifos meus)

Na imageria do eu lírico, revólver e canaviais - violência e alimento, intimamente imbricados - são, assim, complementares, não excludentes, nem chegam a se estranhar. Aliás, o processo de formação da cultura, na visão do poeta, não oculta esse curioso enlace; antes, revela-o, porque se fez e se faz gritantemente, a olhos vistos, sem embaraços maiores, como se surpreende também muito naturalmente na crônica de Antonil, cheia de metáforas expressivas ("bocas verdadeiramente tragadoras", "cárcere de fogo", "fumo perpétuo", "viva imagem dos vulcões, Vesúvios e Etnas", "Purgatório", "Inferno").

"O mapa", se ao mesmo tempo guarda esse tomáspero encontrado no padre italiano, como se ambos os textos estivessem dialogando frente a frente, examinando também realisticamente o mundo circundante, traz de modo igual, quase na mesma proporção, o registro do paraíso terrestre que segue incólume, sem, afinal, o eu lírico passar recibo de culpa. Pois nem sequer faltou aos versos de Fiúza uma referência graciosaà paisagem, com que parece se naturalizar a violência,

na leda margem porosa

fundou seu mundo de luz

sob as mangueiras em flor. (o grifo é meu)

embora tenha sido imperioso mostrar que existem, sim, a barbárie e a morte, que, representadas pelo revólver, não podem se disfarçar de todo em meio à serena paisagem. Muito pelo contrário, porque o revólver é o ser que metaforiza o mapa do estado nordestino, e não o contrário, como talvez devesse ser, já que o desenho do mapa é uma 
abstração, uma virtualidade, e a arma de fogo éo elemento manifesto dessa realidade, o objeto que realmente está presente na cadeia associativa das imagens. Assim, morte e violência existem, como se pode ver, mas não afetam negativamente a ordem sentimental (a presença sorrateira da metáfora "mangueiras em flor" que o diga). O que, fosse outra a solução, poderia trazer o risco de transformar o poema em documento historiográfico, com caráter de denúncia; ou, no extremo oposto, deliciando-se com a beleza natural do lugar, fazer esparramarse chavões líricos de pendor idealizante que não fazem mais sentido atualmente e que o poeta, enfim, mesmo por força da tradição, soube convenientemente pulverizar.

\section{O percurso histórico-poético da fome}

Anarrativaque venhodesenvolvendo-conformando-aàquelacujo recurso temático-estilístico de menção ao açúcar e às frutas reflete, desde o Brasil Colônia, episódios de uma cultura que, apesar de transformações históricas e econômicas visíveis, revela manter-se aclimatada ao ideal mercantil estrangeiro, ${ }^{9}$ ao mesmo tempo que institui um padrão crítico de reflexão sobre as diferenças internas do país - dirige, ainda, depois de quatro séculos de vidaculturale social brasileira, o olhardo poetamoderno. Este, sem lograr apagar o passado de conflitos e ambiguidades que esse conjunto de imagens guarda, interagefortementecomaspressõesexternas, confirmando-as, submetendo-as a novo crivo e também reformulando-as (não gostaria de dizer "negando-as"), na medida em que o texto dialoga

\footnotetext{
${ }^{9}$ Se no passado colonial esse atrelamento do Brasil à cultura estrangeira se dava primordialmente com o português em virtude de todas as circunstâncias verificadas no âmbito da nossa dependência ao colonizador, hoje, ao contrário - com espelhamento científico realizado pela obra científica de um antropólogo notável como Gilberto Freyre -, tal ocorre com a miragem e capacidade de emulação que desenvolvemos em relação ao poderio econômico e cultural amplamente espraiado pelos Estados Unidos. Confira-se também o que diz a esse respeito Souza (2015, p. 43-44).
} 
com tal substrato histórico, até achar a forma justa para tal embate nos limites mesmos da capacidade de simbolização do discurso literário.

Eis, agora, o delineamento de um percurso que vai da cana e dos maracujás até chegar à pera - fruta de origem estrangeira que o brasileiro considera alimento requintado e de gosto não muito atraente ao nosso paladar, acostumados que fomos, desde a Colônia, a alimentos mais doces, como o mel de engenho, goiabadas e bananadas. ${ }^{10}$ Trata-se, entretanto, da frutaescolhida porFerreira Gullar, no poema aquiselecionado para exame; nele, descreve-se uma viagem estético-cultural que implica a sombra de uma fruta pela qual se entrevê o liame com essa "cultura açucarada" ou com, por contiguidade, com outros tipos de alimento. Como se estivéssemos todos mergulhados em estado de uma fome deplorável, não é raro que a memória científica também desvele tais relações. O exemplo mais notável é o discurso antropológico que vem de Gilberto Freyre, pensador a respeito do qual Souza (2015) não só acentuou a participação da herança portuguesa na nossa formação como, imitando o autor comentado, também se serviu do símile da comida para indiciar o espírito de emulação que nos move desde muito tempo:

Para Freyre, a "singularidade cultural brasileira" é uma continuação de Portugal e de nossa "herança ibérica". Para o senso comum leigo, nada mais óbvio. Afinal, falamos o português e muitos de nós gostamos de bacalhau, de sardinha e usamos alecrim no tempero (SOUZA, 2015, p. 41). ${ }^{11}$

${ }^{10}$ Gilberto Freyre, em Casa-grande \& senzala, afirma que herdamos da colonização portuguesa influências árabes no preparo da comida do dia a dia: "Diversos outros valores materiais, absorvidos da cultura moura ou árabe pelos portugueses, transmitiramseao Brasil [...] certo gosto pelas comidas oleosas, gordas, ricas em açúcar" (FREYRE, 2003, p. 299). Nesse contexto herdado, a pera é, realmente, uma fruta estranha nesse vasto pomar.

${ }^{11}$ Gostaria apenas de salientar, com base nesse fragmento que colhi do sociólogo Jessé Souza, o fato de que ele, ao lembrar esse liame entre o Brasil e a herança portuguesa que ainda corre pelo pensamento do país, usou o artifício do exemplo da comida. Se Portugal ainda infunde sobre nós alguma influência, conforme o senso comum, isso 
Mirar o estrangeiro como padrão de comportamento e atitudes é uma estratégia de incansável recorrência para quem busca a formulação de uma identidade. No passado colonial fica ressaltada a marca da dependência da colonização portuguesa; no presente, o modelo é produzido pela fascinação por outro império, os Estados Unidos, que Souza vê no horizonte da constituição da nossa modernidade - e, não por acaso, Freyre também via:

A relação com os Estados Unidos é tão importante para oentendimento da interpretação que os brasileiros fazem de si mesmos que vale a pena reconstituir sua genealogia. Ela é central, por exemplo, para a própria versão dominante do mito nacional elaborada por Freyre (SOUZA, 2015, p. 43).

Com o recorte que resolvi fazer na lírica brasileira, apropriandome, no caso, de imagens icônicas como o açúcar e seus corolários (frutas, doces, melados), a presença metafórica da fruta passa a ser, desde o início, um componente decisivo para compreender, do ponto de vista estético e cultural, o funcionamento da estrutura econômica do país e a presença de seus rastros históricos. A passagem do açúcar da cana à pera, em Ferreira Gullar, demonstra umespírito que, tendo absorvido a cultura colonizadora portuguesa, oferece também como destino a opção modernizadora que vem dos Estados Unidos, momento da produção do poeta em que ele parece dargrandeimportância aumaexpressão maiscosmopolita, talcomo se detecta no seu último livro, Em alguma parte alguma, coletânea saída em 2010. Nesse livro, por exemplo, como diz o poeta em "Galáxia”, partindo

se confirmaria, entre outras coisas, pela preferência culinária tipicamente portuguesa: bacalhau, sardinhas e alecrim. Não quero, com isso, entretanto, ampliar o raio de ação da proposta de interpretação que defendo aqui; quis só mostrar a coincidência no que toca ao apelo à comida como ilustração (embora, no caso de Souza, tal associação pareça ser uma pitada humorística de que ele resolveu se servir, sem consequências para a análise, tão somente para destacar o papel de Gilberto Freyre na interpretação dos dados). 
de uma situação temporal e geograficamente - e muito prosaicamente situada,

\author{
Aqui estive \\ neste \\ banheiro branco \\ [...] \\ aqui estive \\ (estou) neste hoje \\ dia 3 de fevereiro \\ de 2003
}

o eu lírico transforma o incidente biográfico, datado, em uma percepção que elide o sujeito individual em direção a um universal mais flagrante $\mathrm{e}$ ousado, um "fora" que, enfim, se abre em abismo e lança o eu lírico numa vertigem infinita:
lá fora (fora
do banheiro (fora
da casa)
a cidadeéuma galáxia
a mover-se desigual
em seus diferentes estratos
veloz e lenta
e em contraditórias direções

Assim, não estão mais no horizonte da lírica a denúncia social dirigida a umalvo preciso nem a contemplação de qualquer ferida nacional que cause estupefação ou raiva incontida (estamos longe, portanto, do Poema sujo, de 1975). A colonização açucareira é lembrada, mas não aprofunda a dor de sua trajetória sangrenta, violenta. Explode em clarão universal, com que o eu lírico, mais maduro, saído da poesia participante dos Centros Populares de Cultura da década dos anos 1960, demonstra uma superação - estética e política - de dar água na boca. É o que parece demonstrar o poema "Bananas podres 4". A fome, como se pode deduzir, 
é outra, modulada por uma contenção racional - a comida abandona seu posto denotativo e transforma-se em metáfora - que, assim, apazigua a expressão:

É a escuridão que engendra o mel ou o futuro clarão no paladar

Mais adiante, no mesmo poema, a ressonância histórica da opressão - que hoje é só memória - regula o gosto do/pelo açúcar e já não traz o rancor dos tempos idos e vividos, quando o poeta se exilou na Argentina durante o período mais enérgico da ditadura militar no Brasil:

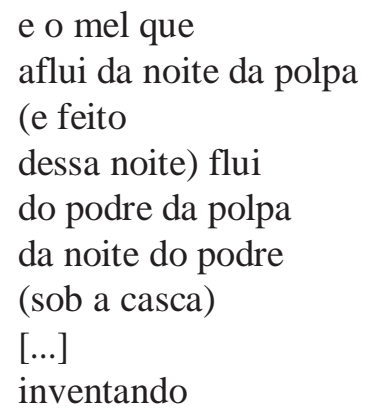

Dessa imageria - da "noite da polpa", "do podre da polpa" e "da noite do podre" à invenção de "um quase alvorecer na quitanda" -, Ferreira Gullarcontempla séculos de história, no circuito que se inicia como açúcar, passa pela noite da ditadura ("noite veloz"?) e chega ao presente, em que, infelizmente, não nascemos de novo, puros e modernos, para consertar os erros do passado, pois énesse "quase" queestamos vivendo, no limiar entre o velho e o novo, nesse limiar que ainda angustia o brasileiro nesta enorme quitanda que é o Brasil. Pululam, assim, latentes, na expressão poética de Ferreira Gullar, esforços estéticos que, no diálogo que ele empreende com o passado, tanto fazem lembrar motivos antigos com que muitos 
poetas brasileiros, desde Botelho, agraciam rasgadamente a paisagem local, principalmente quando se confundia pátria com natureza, ${ }^{12}$ quanto os motivos que, de feição mais crítica, se vêm renovando, sem, no entanto, gozar de independência em face das marcas de nossa dependência cultural em relação ao estrangeiro e, particularmente, à nossa própria história. Conforme vamos ver, a pera, mesmo depurada e alheia ao paladar do brasileiro, não logra forçar o salto para muito além do passado histórico, como talvez gostaríamos que acontecesse (é esse "quase", sofrido e lamentoso, que nos atormenta e atormenta Ferreira Gullar). Pois a tensão entre o suave e o áspero estabelecida nos versos - a declaração, isolada ou simultânea, da doçura e da violência, da falta e da fartura, em vaivéns constantes, na-é praticamente a mesma que perpassa, mutatis mutandis, a realidade extraliterária. Uma realidade que, enfim, também se vê espremida entre as idílicas aspirações de toda a gente e o enfrentamento embaraçoso das dificuldades que, por vezes disfarçadas em delícias, começam no batente do dia a dia, conforme o podem lembrar igualmente "As frutas [que] se produzem copiosas, / E são tão deleitosas" (Manuel Botelho); ou, ainda, num avanço do sentimento que prevê o embate dos polos selecionados, esse "O lado externo do cabo [do revólver] / é de esmeralda corrente [...] o de dentro, também verde, / de canaviais e mangue" (Fernando Fiúza); e, agora, em face dessa gradação praticamente desembocando em uma alegorização, sem muita razão histórica para o otimismo ou para algum tipo de concessão, como está em "as bananas já estavam passadas, quase inteiramente podres naquela tarde" (Ferreira Gullar).

\footnotetext{
${ }^{12}$ No ensaio "Literatura e subdesenvolvimento", Antonio Candido estabelece muito bem esse enlacenoque dizrespeitoà constituiçãodas diversas literaturas latino-americanas, do México à Argentina, em sua busca, de todo eufórica, de uma definição das fronteiras culturais entre o colonizado e o colonizador: "A ideia de pátria se vinculava estreitamenteàdenatureza eem parte extraía dela a suajustificativa. Ambasconduziam a uma literatura que compensava o atraso material e a debilidade das instituições por meio da supervalorização dos aspectos regionais, fazendo do exotismo razão de otimismo social" (CANDIDO, 1987, p. 141; os grifos são de Candido).
} 


\title{
Yes, nós temos peras
}

Açúcar e frutas lembram, associativamente, nosso esplendor e nossa miséria, tanto no âmbito da história quanto no da poesia, cujas mediações são dadas pela sinceridade da expressão pessoal. Crença que Ferreira Gullar, ele mesmo, manifesta, principalmente quando perscruta mais de perto o desenvolvimento histórico do país, sempre irregular e acidentado, com tendências a andar para trás como "caranguejos arranhando o litoral" (expressão extraída da crônica histórica do Frei Vicente do Salvador). O homem-caranguejo, de Vicente do Salvador, é o quase-pronto para ser consumido, de Ferreira Gullar.

A imagem de uma fruta - a pera, a insossa e inodora pera, no poema "Figura-fundo", de Ferreira Gullar, ${ }^{13}$ de que passo a me ocupar vai servir para abrir, e retomar, essa discussão:

\author{
a pintura, digamos, \\ é mentira \\ isto é: \\ uma pera \\ pintada \\ não cheira
}

Sobodisfarcedeumaconsideraçãosobreapoesia, ${ }^{14}$ FerreiraGullar reflete sobre formas de representação de certo real concreto brasileiro

\footnotetext{
${ }^{13}$ Esse poema integra o último livro publicado por Ferreira Gullar, Em alguma parte alguma, de 2010.

${ }^{14}$ Sérgio Buarque de Holanda diz, na introdução a Toda poesia (livro que reúne a poesia de Ferreira Gullar desde o início), que, no poeta maranhense, "a voz pública não se separa em momento algum de seu toque íntimo, de seu timbre pessoal, de esperançase desesperanças, das recordações da infância [...]". Se Sérgio ainda tivesse podido alcançar o último livro de Gullar, de 2010, iria perceber que isso não mudou, ainda que se lhe possa dar outra interpretação. Lafetá, em apoio a esse depoimento de Sérgio Buarque, afirma que Gullar "busca definir-se diante de problemas como a natureza da poesia, o fluir do tempo, a deterioração do corpo, a memória de fatos e pessoas, a morte, a fragilidade das coisas, asrelações sociais, as atitudeshumanas etc."(LAFETÁ, 2004,p. 123-124).
} 
que guarda na memória elos insuspeitos entre as fases históricas, mas perfeitamente conciliáveis do ponto de vista de sua dialetização que só uma leitura interessada nesse ângulo de visão pode sustentar. Em outro patamar de percepção crítica pode-se conceber, como o admitiu Lafetá, ${ }^{15}$ que Ferreira Gullar apenas subjetivou os objetos e os tempos, compreendendo tudo isso matéria de expansão privilegiada de subjetividade do eu lírico. A meu ver, no entanto, penso que ocorre justamente o contrário: o que se dá na obra do poeta maranhense é uma reflexão que se desenvolve gradativamente, desde A luta corporal, de 1954, em direção firme, embora melíflua, à marcha impetuosa da história, não ao seu apagamento ou disfarce arbitrário; e, sendo assim, o eu expandido que Lafetá visualizou se retrai em nome de uma melhor atenção ao problema histórico-social que venho defendendo nesta análise. Ainda que a pera do poema de Gullar pareça estar desligada do mundo circundante - isolada ou solta no ar, no espaço neutro de uma natureza-morta, sem salientar que essa fruta nos parece distanciada do prato do brasileiro, que prefere outras, mais doces e também mais fáceis de encontrar emuma quitanda ou nas feiras populares - , a análise procurará, contudo, verificar que sentido pode ter a pera nos vestígios da trajetória dos fatos sociais vividos. ${ }^{16}$

${ }^{15}$ Diz Lafetá em relação a poemas de A luta corporal, livro de poemas de Ferreira Gullar de 1954, quando ainda era vigente o esteticismo da Geração de 45, que, neles, "a noção de tempo [...] refere-se a uma realidade subjetiva, e falta-lhe a dimensão histórica que permitiria suplantar a sensação de vazio, ao oferecer um sentido concreto àquilo que o 'eu' percebe como ausência de sentido e arbitrariedade. [...] Nem o canto do galo, nem o brilhoda pera seriam inúteis, destinados apenas àmorte, masteriam uma função de beleza (e outras), sempre numa direção positiva" (LAFETÁ, 2004, p. 153-154; o grifo é meu). O tema das frutas - apodrecendo - se associa a um sentimento que oscila entre o recuo da luta social e a promessa de desvendamento desse real concreto brasileiro, já nesse livro de estreia, segundo penso. Nos dois casos, uma forma de resistência, o que configura uma consciência histórica em progresso, não a falta dele, como afirma Lafetá, que, infelizmente, não viveu o suficiente para ver a última publicação do poeta maranhense. A sugestão de Lafetá, entretanto, é bastante motivadora, pois obriga a ver o percurso de Gullar, como ele realizou no ensaio que remeto para conhecimento do leitor.

${ }^{16}$ Em um livro de cinquenta e nove poemas, como é o caso de Em alguma parte alguma, último livro de Ferreira Gullar, seis poemas trazem a metáfora da fruta, sendo que dois desses focalizam a pera. E em todos em geral ressalta certo tom reflexivo, às 
Por que essa preferência por frutas, legumes, produtos alimentícios tirados da natureza, desde Botelho de Oliveira, passando pela crônica dos historiadores e pelos poetas árcades e românticos, nessa busca de representar o chão local? A fascinação continua até hoje. Disso não escapam os poetas modernistas, nem os romancistas da atualidade. Em Milton Hatoum, por exemplo, a natureza e seus produtos que se oferecem ao paladar não deixam de conter aquele gosto de certo orgulho de ser brasileiro, traço pitoresco que já não se espera que haja na produção literária contemporânea, aliás:

Nunca comemos tão bem. Peixes os mais variados, de sabor incomum, cobriam a mesa: costela de tambaqui na brasa, tucunaré frito, pescada amarela recheada de farofa. O pacu, o matrinxã, o curimatã, as postas volumosas e tenras do surubim. Até caldeirada de piranhas, a caju avermelhada e a preta, com molho de pimenta, fumegava sobre a mesa. E também pirão e sopa com sobras de peixe, farinha feita das espinhas e cabeças, bolinhos de pirarucu com salsa e cebola. (HATOUM, 2006, p. 122)

Não é exagero afirmar que se repetem no romancista manauara, como o podecomprovaresse trechode Doisirmãos, amelodiae asintaxe de “À Ilha de Maré", na verdade, certa aparência de um mesmo sentimento, apenas com algum traço aqui, outro ali, de atualização de linguagem. Parecendo continuidade de um projeto escritural que vem de quatro séculos, o roteiro, de sabor nativista (inclusive no mau sentido que esse termo pode ter), é quase o de um folheto turístico que alardeia as belezas e particularidades culinárias de umaregião do Brasil. Como emBotelho de Oliveira, que imaginou um conúbio nada inocente entre frutas, legumes e contato humano visivelmente erótico com a nova terra ("Jaz em oblíqua

vezes mais, às vezes menos, sobre a própria composição artística, que, na proposta de análise que realizo neste ensaio, é atravessada por sentimentos históricos criticamente trabalhados. 
forma e prolongada / De Netuno, que tendo o amor constante, / Lhe dá muitos abraços por amante; $\mathrm{E}$ botando-lhe os braços dentro dela, / A pretende gozar, por ser mui bela"), Hatoum também confere sensualidade a essa relação. Vê-se bem isso nesta passagemem que Domingas, a mãe do narrador Nael, ambos mestiços, agregados no casarão dafamília de origem libanesa, é lembrada pelo filho numacenaemque ela, sensualmente, untao corpo de Omar, o Caçula, com folhas, suco de frutas espremidas na hora, em visível erotização ("Ah, a falta que lhe fazia o corpo do galã desmaiado na rede!"). Logicamente, nesse entrecruzamento das frutas locais com os cheiros do corpo humano, não falta leve sotaque cultista:

Esses cheiros e outros: o das folhas grandes da frutapão, semelhantes a abanos verdes; o do cupuaçu pesado e maduro, cofre de veludo ocre que protege a polpa prateada, fonte de raro perfume. As folhas molhadas com que ela cobria as partes roxas do corpo dele; 0 suco de cupuaçu com caroços para chupar que ela lhe preparava no meio da tarde, quando, revigorado, ele abria os braços para minha mãe e beijava-lhe o rosto com intimidade, antes de sorver a bebida espessa. (HATOUM, 2006, p. 111; os grifos são meus)

Frutas entranham-se, nesses textos, como metáforas da vida; são alimentos que nutrem o corpo mas também, o que é bastante notório, o imaginário sexual, algo a que se assiste desde a casa-grande e a senzala. Tal recorrência só serve para revelar que a constante temática não deixa de ser relevante entre nós, já que a literatura brasileira conta com muitos exemplos disso (Jorge Amado serviu-se muito desse expediente em suas crônicas romanescas, como Gabriela, cravo \& canela e Dona Flore seus dois maridos, apenas para ficar comos títulos mais expressivos da vasta obra do escritor baiano). 
São, assim, variados sentidos que infunde o alimento, mistura de amor, sexo, natureza, sentidos frequentes em textos de qualquer época $-{ }^{17}$ e realizam literariamente um caminho que começa com a história do país, como já fiz notar. Eles fazem parte da paisagem brasileira, da vida que se leva... e, principalmente, da vida que se levava, durante o período colonial. Por essa forma de alimentação adivinha-se o resto, como, não é demais apontar: as frutas e compotas feitas com as frutas da época funcionavam, na vida prática, como alimento necessário à sobrevivência, não meras sobremesas de uma mesa de farturas. Chegavam até a substituir outros tipos de comida por conta de uma estrutural precariedade ou reduzida variedade de sua oferta em algumas capitanias, em época em que os recursos eram naturalmente exíguos, mais em algumas regiões, menos em outras, a depender sempre da vegetação, do clima, das águas existentes no local. Em tal contexto tornam-se as frutas, portanto, compensatórias e complementares, a adoçar a vida do brasileiro.

À falta de alimentos mais nutritivos e substanciosos, mesmo entre famílias ricas, recorria-se a comidas preparadas com excesso de açúcar, feitas de frutas que ainda se podiam aproveitar, para suprir o sustento do corpo: "Afalta de boacomida era compensada pelos excessos de doces: goiabadas, marmeladas, doces de caju e mel de engenho e cocadas" (DEL PRIORI; VENANCIO, 2010, p. 46; o grifo é meu).$^{18}$ Antonio Candido,

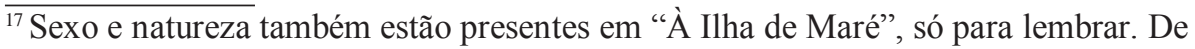
modo grosseiro apareceram também representados em um programa de televisão, produzido na década de 1990, em um quadro do conhecido e popular $O$ domingão do Faustão, da Rede Globo de Televisão, em que atores se serviam de frutas e legumes que tiravam de um corpo nu de mulher, deitada no palco, envolta por tais alimentos, como se ela fosse uma travessa de sushi, para, de modo explicitamente provocante, degustar a iguaria que então estava ali disponível. Pôde-se ver, na ocasião, uma metáfora viva da história da nossa colonização, por meio de uma cena grotesca em que homens, em pé, cercando o corpo da mulher, se deliciam sensualmente daquilo que o corpo de uma mulher pode oferecer. Algo parecido, mas em outro nível de representação, está em "À Ilha de Maré", onde se lê que Netuno, cercando a ilha, "lhe dá muitos abraços por amante; e, botando-lhe os braços dentro dela, a pretende gozar, por ser mui bela".

${ }^{18}$ A esse respeito acrescente-se o que disse Gilberto Freyre: "Já se tenta hoje retificar a antropogeografia dos que, esquecendo os regimes alimentares, tudo atribuem aos 
conforme já vimos, ${ }^{19}$ usa um argumento que pode muito bem encaixarse neste agora: assim como frutas e doces substituem outro tipos de alimentos durante o período colonial, em razão da falta, por motivos vários, eis que a caracterização idealizada, na literatura, da pródiga natureza brasileira, cantada em verso e em prosa, era instrumentalizada para dar uma ideia de fartura e variedade, encarada também como compensação, em favor de uma definição do que é ser pátria no momento exato emque o Brasil precisou desse programa nacionalista, bastante útil ao país que se tornava independente. As inocentes frutas, além de amparadas pela escrita literária, chegaram a ter até um valor político-social expressivo, o de servir, inclusive, à nomeação de engenhos, ${ }^{20}$ passando elas a fazer parte de uma estrutura de poder que ultrapassa os limites do simbólico literário tout court.

Se a aristocrática pera tem toda a pinta de representar um desligamento da premência do mundo da produção e da necessidade mais imediata e necessária à sobrevivência, no caso, do brasileiro — daíé que a pera, reduzida a uma pintura, "não cheira" (e é até bom que nem cheire) —, ela bem pode aparecer, com mais folga e mais felicidade, dentro da memória histórica, como compensação à nossa realidade mais embrutecida. ${ }^{21}$

fatores raçaeclima [...] mesmoentre as classes abastadas, um dos povos modernos mais desprestigiados na sua eugenia e mais comprometidos na sua capacidade econômica pela deficiência de alimento" (FREYRE, 2003, p. 104; o grifo é meu).

${ }^{19}$ Retorne-se à nota 12 deste ensaio.

${ }^{20}$ Colheu-se a informação de que "o plantio e o trato da cana-de-açúcar significavam a possibilidade de participar ativamente na estrutura de poder colonial" (DEL PRIORE; VENANCIO, 2010, p. 46). Mais adiante dizem Del Priore e Venancio: "Muitos batizavam seus engenhos com onome de santos protetores: São Francisco, São Cosme e Damião, Santo Antônio. Outros tinham nomes africanos como Maçangana. Outros ainda lhes davam nomes defrutas eárvores: Pau-de-Sangue, Cajueiro-de-Baixo, Jenipapo"(idem, p. 48; o grifo é meu).

${ }^{21}$ Peço ao leitor deste ensaio que não coloque (nem foi meu propósito fazer tal ilação) o Ferreira Gullar da última fase na mesma prateleira de um Augusto Frederico Schmidt ou de um Alphonsus de Guimaraens Filho, que, em pleno século XX e após as conquistas libertadoras dos modernistas, retrocederam ao verso de feitio parnasianosimbolista, tal como o denuncia Mário de Andrade no ensaio "A volta do condor" (ANDRADE, 1974). O caso de Gullar é outro, conforme eu vejo: é a perquirição da realidade circundante e histórica por meio do disfarce de uma pesquisa estética moderna, fazendo contrastar o ideal da poesia (que ele põe em xeque) com a podridão 
Já a cana, por ser mais dada a figurar na realidade brasileira, tem funcionado menos como símbolo e mais como menção sociologicamente icônica; daí que foi substituída, nesse poema de Gullar, por uma fruta mais distante exótica, a inusitada pera. Do alto da sua frialdade antitropical, ela pode revelar a atitude mais sutil, menos acalorada, desse eu lírico, voltado a instigar no leitor uma maior capacidade de problematização da realidade social em torno da metáfora empregada:

a pera pintada a falsa
pera
por ser mentira
(por ser
cultura e não natura)
desta sorte
nos alivia
da perda e do podre
da morte (o grifo é meu)

"Por ser mentira", ou - dentro de outra lógica, que não a poética - apesar de ser mentira, mas justamente "por ser cultura e não natura" é que a pera nos livra ou, como está dito nos versos, "nos alivia da perda e do podre da morte". O sentido de "aliviar" é primo-irmão de "compensar". Esse seria o jeito de dizer que se faz poesia para reparar nossa miséria e infelicidade, o que não chega a ser estranho em literatura como a nossa que se acostumou a ver no ato simbólico uma forma de aguentar a realidade na medida em que a idealiza, passando por cima dos seus defeitos e lacunas. A esse propósito, vale a pena lembrar que Candido (1987, p. 141), julgando a representação que os escritores românticos fizeram da ideia de pátria, servindo-se da imagem plástica da natureza, sempre muito encantadora e feliz, afirmou que "ambas conduziam a uma

existencial e social (que ele funde à pesquisa formal do poema e assim neutraliza o gesto de apenas indagar as razões da poesia no mundo moderno). Realiza o poeta, pois, uma alta página da lírica brasileira, já no século XXI. Página socialmente corrosiva. 
literatura que compensava o atraso materialea debilidade das instituições" (o grifo é meu). No contexto de Ferreira Gullar, já em pleno século XXI, embora não se possa mais medir a realidade pelos mesmos critérios românticos de avaliação, a memória cultural não consegue apagar os rastros das frutas. Que retornam. Ainda que as motivações para evocálas possam ser outras.

No poema "Desordem", na mesma coletânea, Ferreira Gullar ratifica a semântica da pera como um ser que oferece a outra face, a podre, espécie de "máquina viva" que ampara e situa a fruta na vida moderna. É como se da pera que se oferece à contemplação extasiada nascesse - ou dela se escondesse, não de todo, porém - a podridão do mundo, que, apesar de não querer aparecer, surge nessa apresentação da composição dialética que a própria realidade impõe:

\author{
uma pera \\ também \\ funciona \\ como máquina \\ viva \\ enquanto quando \\ podre
}

Nesse poema, como também está em "Figura-fundo", a pera é um objeto de apreciação única, nublando e substituindo o real: quer como fruta carnuda, meio aguada, inodora, mas bela na sua solidão altiva, indiferente à vida que, entretanto, por suposta, procura ocultar; quer, por outro lado, como agora, como uma "máquina" afinada com os novos tempos, mas igualmente deletéria, a lembrar nossa desordem cotidiana e, talvez, o barulho que vem das ruas. Antes, fruta; agora, máquina. Pois, conforme já dito no verso, é "cultura", não "natura":

instala-se a anarquia

dos ácidos 
e a polpa se desfaz

em tumulto

A escolha dos termos com que se descreve o processo da deterioração do tempo e do ambiente brasileiro não poderia ser mais oportuna: a fruta natural, com seus “ácidos", desmancha-seem "tumulto", palavra mais afeita ao mundo social do que à natureza. Seja qual for a situação, a pera ainda quer exercer o fascínio que exercia aos olhos do colonizador, postado diante da Ilha de Maré, vendo peras que não existiam ali, na paisagem baiana tropical, podendo apenas sonhar com elas. Mas, diferentemente de antes, hoje, em situação de mais realismo, já se admite que ela indicie - por contraste entre a altiva idealização e o que se situa mais abaixo, "água rala e azeda", "lama" — uma podridão que, ainda que negada no plano manifesto do poema, subjaz à sua imagem pomposa e sobe à superfície do dizer, só pelo simples fato de isso ter sido nomeado. Apesar de poder, ao incauto ao menos, ocultar — sem ocultar-se, decisivamente - o escatológico da vida brasileira, a pera "se desfaz em tumulto", guerra, rebelião, insatisfação com os destinos do país. Ou, ainda, "se dilui em xarope", remédio difícil de tomar e sem capacidade de cura. A pera em sua plenitude é coisa para inglês ver, é mercadoria de exportação — nesse sentido é que se pode dizer que, no poema, ela se universaliza e, como tal, opera como sinônimo de poesia - , ao mesmo tempo que se dá como escuridão. O embaralhar das realidades - a da fruta notável e a do "podre da polpa", da "noite do podre", entrelaçadas ambas, ambíguas e ambivalentes - é a própria tarefa do poeta, que, como está colocado no poema "Fica o não dito por dito", justamente por não dizer claramente,

não revela

o oculto:

inventa

cria 
o que é dito

(o poema

que por um triz

não nasceria)

\section{Em outras águas}

A eleição, em Gullar, do motivo da fruta, que é a continuação e prolongamento da ideia desse "comércio de doçura", ao qual se imprime, como sua contrapartida negativa, toda sorte de risco de existência (da própria doçura, inclusive), encontra, no passado histórico, uma justificativa para seu diálogo. E, se é tudo isso mesmo o que se depreende dos versos de "Figura-fundo", "a pera pintada" (ou "a falsa pera") produz esse efeito de compensação, pois tal fruta, por não serverdadeira,

não se dilui

em xarope,

água rala e azeda, é

pintura e por isso

dura

mais que qualquer pera verdadeira

Mas dizer é uma forma ainda de existir, ao menos no circuito poético, cuja expressão é carregada de tensão e pulsões que, de resto, se extraem motivadoramente do plano da realidade. A pera afirmativa (em mais de um sentido) remonta ao passado histórico e, como resultado praticamente inesperado, permite reconhecer tais rastros na imageria que Ferreira Gullar monta. A pergunta que se pode fazer, pois, a um poema como "Figura-fundo" (que, na aparência e no seu recorte de linguagem, mais parece ser um metapoema) é a seguinte: como versos de tal feição exprimem a realidade local, com seus desenganos e sentimento de derrota? A negatividade que o senso comum enxerga no termo "mentira" 
- afirmada, entretanto, como predicado nominal para "pintura", assim como, no mesmo diapasão, o predicado verbal "não cheira" se aplica a "uma pera", resultando ambos os sujeitos de oração, "pintura" e "pera", completamente valorizados - só serve para ressaltar o peso estético do metapoema. De outro modo - nessa contraposição entre a pera que não cheira, porque é falsa, e o fato de que ela, por isso mesmo, "não se dilui em xarope, água rala e azeda" - , fica salientado que a dimensão histórica do poema, pretensamente abafada pela mentira da pintura, se imiscui na cena, evocando a realidade de uma natureza que, limpa um dia, termina por se conspurcar de uma vez por todas.

A água - "rala e azeda" - que faz parte da paisagem pode ser lida, na contemporaneidade, como a presença incômoda que deseja ser superada pela ação da arte (afinal, como diz esse eu lírico prevenido e atento, trata-se de cultura, que é construção, elaboração, execução, e não de natura, onde as coisas são como são, até serem modificadas pelo homem). Surge agora nesse contraponto trabalhado em "Figura-fundo" a imagem das águas, nada aproveitáveis, todas poluídas, para dizer o mínimo. Comparativamente, sabe-se que, no registro de cronistas e poetas do passado colonial, as águas eram percebidas como infindas e frescas e revelavam, como num espelho, a diferença do Novo Mundo em relação à Europa sofrida por suas guerras, suas doenças endêmicas, suas formas dramáticas de civilização. Sim, o Brasil, nessa visão, era o espelho invertido que emprestava um ar novo a quem viesse por aqui, um paraíso perdido que, finalmente, foi achado — todo, inteiramente natureza, não cultura (ainda). Na trajetória em que se encontra o eu lírico de "Figura-fundo", sai invertida a posição dos termos. Isso porque a fórmula de Gullar é, como estamos vendo, propor mesmo a história que está sendo contada e assumir, definitivamente, a vertente crítica que se espera de umpoeta moderno, no geral, e de um poeta compromissado com os caminhos e destinos políticos da nação, por outro.

Para um observador daquela época, porém, 
Em nenhuma outra região se mostra o céu mais sereno [...] o sol em nenhum outro hemisfério tem os raios tão dourados [...] as águas, ou se tomem nas fontes pelos campos, ou dentro das povoações nos aquedutos, são as mais puras. (ROCHA PITA, 2011, p. 28; os grifos são meus)

Falar afirmativamente das águas que subjazem à figura da pera, ainda que isso se dê pela negação ("não cheira", "não se dilui"), é o mesmo que dizer aquilo que ela, na verdade, esconde, o xis da questão. Se o poema não oculta nem esconde (diz o poeta em "Fica o não dito por dito") e "se a fruta não cheira no poema" é porque o poeta "inventa" uma matéria e um assunto, oferecendo um problema para pensar. Ele "cria" (não no sentido romântico do termo) e "só ao dizê-lo vai saber o que precisava dizer" o que "a vida provisoriamente permite". Nesse jogo de dizer e desdizer, e inventar (pela dicção que a arte oferece), a vida que se vive extraliterariamente termina por constituir, de fato, a matéria da poesia, de que se não pode fugir, a não ser provisoriamente (diz ainda o poeta). Sem poder obscurecer completamente esses sentidos subterrâneos, os quais, para quem é da cidade brasileira contemporânea, têm sido tenebrosos, o ato de escrever/ler o poema é como adentrar o terreno invisível, situado abaixo da pera e dar de frente com a lama e a podridão que mal conseguem se disfarçar. É como visitar uma cidade e querer tão só dirigir o olhar para o alto, vendo seus prédios, admirando a cúpula de seus monumentos. Mas visitar também é olhar para baixo, ver suas praças, as imperfeições da pedra e do asfalto, a lama que se acumula nos meios-fios das calçadas.

É o que nota, por exemplo, um ensaísta e jornalista americano, Benjamin Moser, que tem refletido, na atualidade, sobre a vida cultural do Brasil, onde morou por quase duas décadas. Diz ele que a "infraestrutura" do lugar, assimentre aspas, conforme colocou, é o que mais chama atenção em quem chega a uma cidade pela primeira vez. "Infraestrutura", para ele, 
é a "palavra que resume alguns aspectos da vida, inclusive as primeiras coisas percebidas pelo visitante". Se, continua Moser, o país melhorou em alguns índices horizontais de consumo, trazidos pela estabilidade da moeda, criando a ideia de ampliação de poder de compra entre as diferentes classes sociais, a "infraestrutura" - sintomaticamente relacionada comas águas, ou restrita a elas — não apresenta os mesmos resultados. Para isso, toma as cidades de São Paulo e do Rio de Janeiro como representações emblemáticas das considerações que faz:

Mas o que não havia melhorado era a "infraestrutura" [...]: o canceroso tubo de esgoto em que o rio Tietê se tornara a olhos vistos, entre o aeroporto internacional e o centro de São Paulo; a baía de Guanabara, negrae oleosa, no caminho entre o aeroporto e a cidade do Rio de Janeiro. A questão do saneamento, que tem ligação direta com problemas ambientais e de saúde pública, era apenas um problema de "infraestrutura" - e poderia representar tantos outros. (MOSER, 2016, p. 76; os grifos são meus)

A saúde das águas é o indicativo pelo qual se mede o grau de civilização, de acordo comessa visão (talvez, por isso, RochaPita julgasse viver no paraíso). Águas dos rios, das chuvas, do mar. Águas marítimas às quais o brasileiro sempre esteve ligado, pois que ele foi formado, como diz Sérgio Buarque de Holanda em Raízes do Brasil (1995, p. 103), à sombra e ao abrigo de uma "colonização litorânea", emuma espécie de corredor que é uma verdadeira faixa de terra a estender-se ao longo da costa. Teria ficado apenas o litoral sob a vista do colonizador, que, assim, destina o interior à posição de segundo plano para sua exploração e povoamento, adiando sempre a hora de penetrar o continente. O litoral, branco e resplandecente ao sol, ficou com aparência de casca, superfície de uma civilização. Casca de uma fruta mal arrancada do pé. Concha - deslustrosa que seja, no dizer de Manuel Botelho de Oliveira. 
No poema "Figura-fundo" duas constantes parecem cruzar-se a todo instante: a fruta que é a fruta da tela (e do poema ele mesmo) e a fruta que nasce no pé (a pera verdadeira). Uma se eterniza na pintura que a perfaz; a outra se dilui em água suja e azeda. Pela opção estética do poeta, prefere-se a primeira à segunda; e nisso parece não haver diferença, ao menos assim de cara, entre Ferreira Gullar e Manuel Botelho, jáque ambos se deixam seduzir pelas aparências, apesar de que o poeta moderno não se impede de dialetizar a presença desse fora e desse dentro e desfaz, portanto, a rala abrangência da expressão.

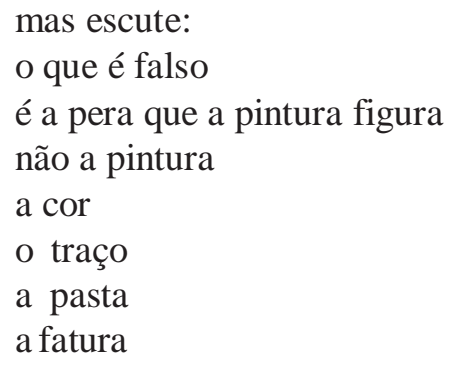

$\mathrm{E}$ - o que poderia ser uma agravante nesse comparativo ligeiro entre Gullar e o poeta seiscentista - a decisão que Gullar toma a respeito do próprio método de composição se reverte a favor do desnudamento do ato literário, não porque seja imperioso, em tempos de modernidade, dizer que se executa o projeto de escrita, mas porque, sobretudo nesse caso particular, se faça coincidir o estatuto de ficcionalidade do objeto ("o que é falso é a pera") com a verdade do ato ("não a pintura"). Entre o ato e o resultado entranha-se a história que o poema conta, nos seus interstícios, tomando uma linha de tradição que vem de Botelho. A história contada flui e reflui na paleta do artista, que ora idealiza, ora investiga.

Ferreira Gullar, conforme o método de trabalho que ele expõe, recua da verdade da pera e distrai-se com a pera que não passa de uma mentira (a que está na tela, ou no poema, mera representação ficcional do 
modelo lá fora, e que, no final, é a única coisa que realmente importa ao esteta, que faz supor, ao menos por cima, ser desprezível toda e qualquer referência à realidade extraliterária). Nos dois casos, uma declaração que faz, entretanto, avultar a história, capacitando o leitor tanto para a idealização quanto para a reflexão (o que, claro, depende do nível de leitura em que se está). Como se achasse pouco, o eu lírico, do alto do seu refinamento esnobe, recua ainda mais, afasta-se da pera pintada e chega ao que se pode chamar de estrutura ou, em linguagem aristotélica, execução da forma. Nas palavras de Gullar, pode-se dizer simplesmente "pintura pura", expressão que, aliás, nada tem de novo e remonta a pesquisas estéticas do final do século XIX:

por que então

não fazer

em vez da pintura-pera

a pintura-pura?

Quando se atenta para a poiésis em si, está-se no terreno de uma abstração da qual deverá surgir algum produto novo, mas num trajeto que se deu ao contrário: tudo começa por escapar da representação proposta inicialmente quando a pera, pronta, se exibia ao espectador; daí, evoluir até chegar à pintura pura onde as formas anteriores já se dissolverame, delas, ficaram apenas "a cor, o traço, a pasta, a fatura"; e, por fim, em face de um pretenso realismo, voltar à pera que tinha sido borrada, mas agora diluída nas águas onde se mergulha o pincel para limpá-lo.

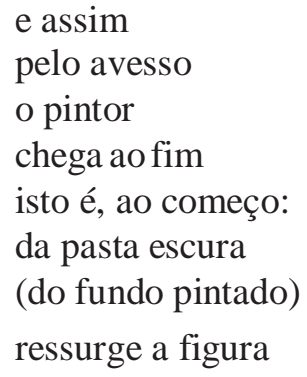


Dramatizando, nos versos, a ideia de que a constituição da pureza, para ser percebida como tal, não vive sem a atividade em que há sinais de sujeira (de construir e desconstruir, simultaneamente, fazere desfazer) que lhe permite existir - portanto, até que ponto se pode dizer que há, mesmo, arte pura? - , Ferreira Gullar, ao menos tão precariamente, faz da fruta uma invenção que, no entanto, não pode ser avaliada sem que se conclame, aqui, um território pleno de historicidade. A linha que separa, para voltar a usar os termos empregados pelo poeta, a "pintura-pera" da "pintura pura" é, como se vê, bastante tênue, esgarçada, para o quê concorrem as águas que a diluem e que, evocando sutilmente a realidade brasileira, se convertem

na escuridão

(na pasta, na lama)

os verdes os azuis

na suja

matéria sem luz

Digamos, então, que a pintura, assim como as cidades observadas por Moser, tem uma "infraestrutura"; e os versos acima transcritos o revelam bem: sob a pera altiva, as águas - pasta (dos tubos de tinta), lama (dacidade, da sujeira do país)! Nesseparalelo entre a linguagem artísticaea historiografia (a antiga e a atual), vê-se que pouca diferença há no emprego dos termos: a lama, a imagem concreta da podridão que aparece na poesia de Ferreira Gullar aparece nos noticiários da televisão e dos jornais diários abordando a corrupção no país. Agora não parece casual nem é de estranhar que termos ligados ao campo semântico da água abundem nos registros poético e jornalístico, senão também nas conversas comuns. Seé, como Moser afirma, pela infraestrutura que se conhecem verdadeiramente o país, a região, a cidade e se tal infraestrutura começa onde começam as águas do lugar, saneadas ou não, temos como hipóteses de leitura que o eu lírico ou sabotou a si próprio, fazendo sumir do horizonte o charme sublimatório dapera, outeve malícia suficiente para não deixar de engastar 
nos versos sua visão crítica do paraíso, pela dissolução da própria pera que antes encantava o olhar: as águas, como já foi observado, são, sim, ralas, azedas, pasta, lama...

Assim, entre a poesia e a paisagem urbana nacional moderna ( sim, porque da antiga paisagem Rocha Pita só extraiu frescor, pureza e beleza), ${ }^{22}$ o real é uma fímbria, um limiar que mal disfarça sua precariedade, sua sujidade. É uma tira de terra (ou de águas) por onde se desenvolve, obliquamente que seja, a crítica social que o poeta moderno desfere contra o próprio pé. É do Brasil que se fala, afinal. Tal tira de terra, uma espécie de franja prestes a obscurecer a sua própria aparição, confunde-se - por esse conúbio de terra e águas - com a faixa de litoral que os portugueses apenas enxergaram enquanto "se esqueciam" do resto. O país, para o colonizador, restringia-se a ser uma vereda de aventureiros, de tal modo que, na ocasião, foi considerado que "a colônia é simples lugar de passagem, para o governo como para os súditos" (HOLANDA, 1995, p. 99), da mesma maneira que a Península Ibérica sempre foi tida pelos europeus como a formação de acidente geográfico incluído na denominação genérica de "territórios-ponte pelos quais a Europa se comunica com os outros mundos", espécie de "zona fronteiriça, de transição, menos carregada, em alguns casos, desse europeísmo que [a Espanha e Portugal, sem falar da Rússia e dos países balcânicos], não obstante, mantêm como um patrimônio necessário" (idem, p. 31).

Da mesma forma que o modo como são tratadas no Brasil as águas em que Moser reparou e que se definem como nossa infraestrutura, separando-nos dos países desenvolvidos cuja infraestrutura não padece do mesmo jeito, as águas atlânticas nos isolam do mundo ocidentalque pertence ao chamado centro. Essas águas se diluem em consistência e valor à medida que chegam aqui, batendo em praias brasileiras, quando,

\footnotetext{
${ }^{22}$ Quero só relembrar o que Rocha Pita disse das águas brasileiras em um excerto já transcrito antes, neste ensaio: “[...] as águas, ou se tomem nas fontes pelos campos, ou dentro das povoações nos aquedutos, são as mais puras" (ROCHA PITA, 2011, p. 28).
} 
enfim, segundo a sagaz interpretação de Ferreira Gullar, azedame tornamse ralas. Assim, não é fortuito dizer, quando algo aqui não dá certo, como diz o senso comum, que fezágua. ${ }^{23}$

\title{
Perto de concluir, mas sem ponto final
}

O Brasil não criou águas novas no que diz respeito a concepções literárias que viessem a se universalizar. Os estilos literários, as modas artísticas, as tendências de romance e poesia, as vanguardas estrepitosas que sacudiram a experiência moderna e a modernista vêm do Velho Continente. Apenas se deu, por aqui, uma absorção com algumas alterações e adaptações, todas necessárias e convenientes ao clima local. A fome de cultura eruditae a aspiração ao novo são inquietações que não raro acometem os artistas, mas não os têm, ao menos na literatura brasileira, credenciado a abrir caminhos diferenciados. Não chega a surpreender que apareça ainda hoje um poema como esse de Ferreira Gullar, "Figura-fundo", em que se discute, por inversão dos seus significados, qual é o elemento fundante do texto, qual o elemento que lhe sobrevém, dentro de certa apresentação aristocratizante de sua proposta e linguagem. Rompendo com uma história linear, o poema subverte a ordem temporal

\author{
Pintar a partir de então \\ é despintar \\ fundir a forma \\ na escuridão \\ (na pasta, na lama) \\ [..]
}

\footnotetext{
${ }^{23}$ Para ficar evidente que a expressão "fazer água" continua sendo usada, muito usada, entre nós, seleciono uma frase da reportagem "A conta era para todos", assinada por Marcelo Sakate e colhida da revista Veja, de 29 de março de 2017, na página 66, em que o articulista afirma o seguinte: "Ainda nem começou e [a reforma da Previdência] já estáfazendo água”, ou seja, tende aofracasso, tende a não darcerto, a desmanchar-se.
} 


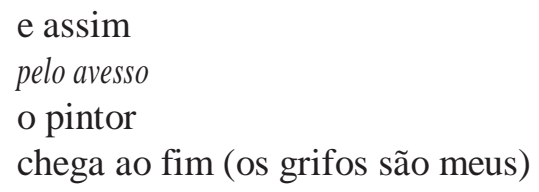

e confunde a orientação dos espaços pelos quais nos movimentamos e damos sentido às coisas que estão em volta. Nesse sentido, a pera, o objeto mais visível do poema, ao mesmo tempo que representa um modelo distanciado dos nossos hábitos alimentares e, por extensão, do nosso perfil cultural mais característico, confirmando um olhar que ainda se deixa seduzir pelo que vem dos centros de prestígio e que por vezes nos é imposto, é também - ao lado da prática da metapoesia, bastante difundida entre modernos - um traço de originalidade, pois faz de quem tem fome e vive em uma sociedade ainda às voltas com sérios problemas infraestruturais alguém que se pergunta sobre seu passado, com o qual estabelece amarras muito evidentes:

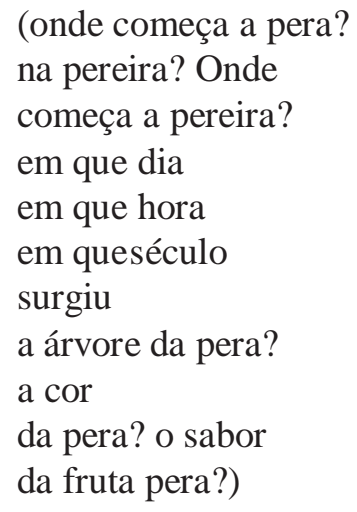

É, assim, enorme o desejo de situar o Brasil dentro do Brasil, conectar suas origens e promover um encontro com a sua definição, sempre adiada, para sempre irresolvida. É como se se tratasse da existência de um mundo profundo a ser descortinado dentro de outro (tal qual a Capitu adulta, saída do interior da Capitu adolescente, delineadas 
ambas e confrontadas também pelo narrador Bentinho, segundo o qual o leitor haveria um dia de reconhecer que "uma estava dentro da outra, como a fruta dentro da casca") ${ }^{24}$ A poesia moderna de Ferreira Gullar açambarca-se da de Manuel Botelho e das inspirações historiográficas de Rocha Pita, Ambrósio Fernandes Brandão, Gilberto Freyre, Jessé Souza, passando pelo romance de Milton Hatoum, até dar de frente com a realidade atual, alvo de críticos e historiadores. Ao inscrever-se nessa linha de pesquisa, Ferreira Gullar vê latejar, no discurso poético que armou, as experiências do passado que ele passa a ler e a desfiar. $\mathrm{O}$ percurso da constante temático-estilística das frutas e do açúcar evoluiu de sua euforia colonial a uma desolação que não tem mais tamanho. $\mathrm{O}$ que fica são indagações de perplexidade para as quais parece não haver respostas ("onde começa a pera? na pereira? em que dia, em que hora, em que século surgiu a árvore da pera?").

Diante de indiscriminadas etão amplas questões - analisadas de perto nossas ambiguidades que envolvem, grosso modo, nosso "constrangedor provincianismo", por um lado, e, de outro, nosso "aristocracismo compensatório de país colonial" $-{ }^{25}$ resta, no fim, identificar os motores da história que possam dar conta dessa narrativa. A história, "que dá para tudo", como disse Brás Cubas, "uma eterna loureira" - muito entre nós, particularmente, também ambígua, também fácil de ser manipulada - , apenas indicia que motores são esses e investiga qual a motivação capaz de fazer o poeta nacional ainda suspirar por uma pera, para depois desejar uma "pintura-pera" e, no limite, pretender uma "pintura pura", nessa gradação. À parte as paronomásias, o que há aí são elucubrações em torno do mesmo problema: a difícil revisão do Brasil por meios decididamente poéticos, mais pelo que o poema esconde do que pelo que ele afirma.

Se do poema de um modo geral se diz que, como discurso, escamoteia a realidade, esta, por si só, como diz Souza (2015, p. 9), "não

\footnotetext{
${ }^{24}$ A passagem destacada está no último capítulo de Dom Casmurro, intitulado "E bem, e o resto?". O grifo que aparece na transcrição da passagem é meu.

${ }^{25}$ As expressões entre aspas são de Antonio Candido (CANDIDO, 1987, p. 157).
} 
é visível a olho nu, o que significa que o mundo social não é transparente aos nossos olhos", ainda mais em um país como o Brasil, cuja história e cuja retórica, segundo versão de outro analista arguto, são "francamente imperialistas" (MOSER, 2016, p. 99), da mesma forma que parecem ser imperialistas - e sobremaneira arrogantes - as personalidades de muitos autores da literatura brasileira. De José de Alencar à arquitetura pretensiosamente futurista de Oscar Niemeyer, temos uma narrativa que oscila entre atender a certo senso de realidade e dobrar-se à megalomania impulsiva que mal se podeconter nos meios intelectuais, atéhoje, por sinal. Quem conhece, por exemplo, José de Alencar mais de perto sabe que ele não era o homem idealista e mesmo ingênuo que parecia ser, por força de seu projeto de nacionalização das letras conforme o padrão idealizante romântico de sua época. Era um homem que chegou a apontar o dedo em riste em direção ao imperador, insistindo, quase num gesto insano, em sua nomeação para o Senado. Ou, por outra, na condição de deputado, o romancista propôs em 1861 uma emenda ao orçamento pela qual excluía perversamente uma ajuda de custo sob a rubrica de apoio às artes que o ator João Caetano até essa data recebia e que, a partir desse incidente, deixou de receber, passando a afogar-se em dívidas, até morrer à míngua dois anos depois, só porque Caetano se recusou a protagonizar no teatro o drama O jesuíta de que tanto Alencar se orgulhava. ${ }^{26} \mathrm{Mas}$, em compensação (mais uma vez a ação gloriosa da "compensação" entre nós), a pintura da natureza que brota de suas páginas é generosa, exuberante, grandiosa, espetacular, e isso é apenas um disfarce da violência que nos engolfa dia a dia. Pois, como diz ainda Moser, "enquanto a energia americana havia dirigido sempre para fora - contra índios, britânicos, mexicanos, contra todos - , a energia dos brasileiros fora canalizada para dentro" (idem, p. 105). E, para tal, é preciso inventar o país das delícias que comovem e encantam, iludem.

\footnotetext{
${ }^{26} \mathrm{O}$ episódio ocorrido entre José de Alencar e João Caetano é descrito exemplarmente por Cunha (2015, p. 54-55).
} 
Eis aí, Alencar incluído, uma boa parcela da elite nacional que, vinda das letras ou da política, legisla em seu próprio nome e sacrifica seu povo, com vinganças mesquinhas, no particular, com planos econômicos perversos, no geral, planos que nunca dão certo, ou em parte ou completamente. Elite que libera programas sociais que poderiam funcionar muitíssimo bem, desde que fossem bem administrados e não desperdiçassem tempo e dinheiro, e que terminam por ir para o ralo até atingir as águas ralas e azedas. Na base dessa operação, como diz o outro, o que há, na verdade, é "xarope", "lama", "suja matéria sem luz". No entanto, o efeito disso - aquilo que aparece para o consumo imediato e que brilha na escuridão -é surpreendente: a pera excele em sua magnitude estética, resplandece no alto do texto, não parece que pode se desmanchar em xarope, porque é uma "mentira verdadeira". Tudo é realizado, enfim, para não ver a pera fazer água (embora faça); e por isso é que o eu lírico prefere a pintura pura, porque, ao menos assim, ela nos alivia - compensa (mais uma vez, até quando?) - do podre da vida e da morte.

Ao lado da sonsice do poeta, atitude aristocrática que mais ofende do que dá bons frutos (sem querer forçar o trocadilho), reina quase serena uma providencial obscuridade, com todas as sombras de que é capaz a índole verbosa do poeta lírico, que, assim, traduz uma tristeza endêmica:

\author{
E o pintor então dissolve \\ a figura da pera \\ na pasta escura do fundo \\ para \\ sem mentira \\ dizê-la \\ e nela \\ dizer o mundo
}

Como o percebeu Paulo Prado, espécie de Antonil do século XX, também chegado a umas metáforas contrastantes, o país não consegue 
esconder seus absurdos: "Numa terra radiosa vive um povo triste" (PRADO, 1997, p. 53). Prado viu no passado colonial algo que bem pôde ser apreciado no Brasil em vias de modernizar-se e, se vivesse ainda hoje, veria também, no Brasil industrializado e mais avançado economicamente: a contradição e a ambiguidade que regem o poema e a vida social.

Para sustentar a quimera do ouro que foi a loucura da época, sempre latente e insistente em todos os empreendimentos, era, no entanto, necessário viver e trabalhar a terra para o sustento diário: daí por todo o século XVI o lento progresso da lavoura incipiente e do comércio rudimentar. (PRADO, 1997, p. 101; os grifos são meus)

Em tudo que se faz no Brasil combinam-se "quimera", "loucura" e trabalho duro para garantir o "sustento diário", numa unidade que a linguagempoética, mais aparelhada para intuir as contradições, captabem. Por sua vez, o poeta maranhense certamente gostaria de ficar entre aqueles que não precisam pegar no pesado (melhor, então, ficar do lado da quimera e da fantasia), como deixou pressentido no poema "O açúcar", que faz parte da sua fase mais militante, aparentemente à esquerda, mostrando serenamente que o que a esquerda moderna quer, desde então, é também consumir, ${ }^{27}$ entrar na ordem capitalista e não pegar nas armas nem ficar martelando certo discurso de contestação contra tudo e contra todos. ${ }^{28}$

\footnotetext{
${ }^{27}$ Nesse caso, é oportuno fazer a distinção entre o que é ser "de esquerda" e o que é ser "esquerdista", de acordo com Moser (2016, p. 96). Pode-se ter pensamento de esquerda sem ser esquerdista. Ohomem instruído, de classe alta ou média alta, pode ter uma visão de esquerda, mais coerente com os novos tempos, que se horrorize com a ganância dos banqueiros e queira ver promovido o bem-estar coletivo, revisando valores capazes de atender às necessidades sociais do seu tempo, não precisando, para isso, ser esquerdista, ou seja, ter algum ímpeto revolucionário que possa pôr em xeque o sistema capitalista ou, se não for isso, vise a uma alternativa radical de poder.

${ }^{28}$ Isso é dito claramente por Bosi (2010, p. 122-123): "Partidos social-democráticos tidos por esquerdizantes voltam-se hoje para a inclusão do maior número possível de trabalhadores nos quadros formais da economia capitalista, facultando-lhes o acesso a alguns bens de consumo e descartando abertamente o recurso à luta de classes, outrora
} 
Para quem se lembra desse poema, o eu lírico aristocrático resolve numa manhã em Ipanema adoçar seu café, bebê-lo e, claro, continuar contemplando a paisagem do bairro chique carioca. De súbito, como é o que acontece em todo poema lírico, ocorre um lampejo subjetivista que deflagra a cena lírica, não se sabendo exatamente como e por que começou nem quando acaba. Nesse rasgo de lucidez, o eu lírico de "O açúcar" dana-se a recordar o percurso histórico da produção do açúcar no Brasil das usinas e, em meio à manhã morna e ensolarada, da qual não abre mão, vislumbra

Em lugares distantes, onde não há hospital nem escola, homens que não sabem ler e morrem de fome aos 27 anos plantaram e colheram a cana que viraria açúcar

Mas a visualização/recordação desse quadro para lá de dramático, em tudo degradante e penoso, não o impede de consumir gostosamente o café adoçado com esse açúcar branco e suave que só é o que é porque resulta, sempre, de uma modalidade torpe e criminosa de trabalho que comumente é realizado "em usinas escuras" onde

\author{
homens de vida amarga \\ e dura \\ produziram este açúcar \\ branco e puro \\ com que adoço meu café esta manhã em Ipanema
}

pedra de toque do marxismo ortodoxo. A generalização do trabalho assalariado é a meta pragmáticae semhorizonterevolucionário dos social-democratas pós-modernos, oque confirma, uma vez mais, a entropia dos programas radicais das antigas militâncias de esquerda" (BOSI, 2010, p. 122-123) 
Ou seja: de nada adiantou a reflexão. $\mathrm{O}$ eu lírico, cujo traço maior de personalidade beira quase a violência dos antigos senhores de engenho, da época de Manuel Botelho, vai terminar - de fato, muito autoimperialmente, apesar de toda a consciência da outra violência, a do embrutecimento do trabalhador - por adoçar seu café. E degustá-lo na placidez daquela manhã. O açúcare as frutas estão definitivamente atados à nossa história e à nossa literatura. Doces e amargos. Doces bárbaros.

\section{Referências}

ANDRADE, Mário de. A volta do condor. In: ANDRADE, Mário de. Aspectos da literatura brasileira. 5. ed. São Paulo: Martins, 1974. p. 141-171.

BOSI, Alfredo. Voltando ao ponto-conceitos em movimento: ideologias, contraideologias, utopias. In: BOSI, Alfredo. Ideologia e contraideologia: temas e variações. São Paulo: Companhia das Letras, 2010. p. 119-140.

BRANDÃO, Ambrósio Fernandes. Diálogos das grandezas do Brasil. Brasília: Senado Federal, 2010. (Edições do Senado Federal, 134).

CANDIDO, Antonio. Literatura e subdesenvolvimento. In: CANDIDO, Antonio. A educação pela noite \& outros ensaios. São Paulo: Ática, 1987. p. 140-162.

CUNHA, Martim Vasques. A poeira da glória. Rio de Janeiro: Record, 2015.

FIÚZA, Fernando. Alagoado. Belo Horizonte, 2008.

FREYRE, Gilberto. Casa-grande \& senzala: formação da família brasileira sobre o regime da economia patriarcal. 47. ed. rev. São Paulo: Global, 2003. 
FURTADO, Celso. Formação econômica do Brasil. 12. ed. rev. São Paulo: Companhia Editora Nacional, 1974.

GULLAR, Ferreira. Em alguma parte alguma. 6. ed. Rio de Janeiro: José Olympio, 2013.

HATOUM, Milton. Dois irmãos. São Paulo: Companhia das Letras, 2006.

HOLANDA, Sérgio Buarque de. Raízes do Brasil. 26. ed. São Paulo: Companhia das Letras, 1995.

KOTHE, Flávio R. O cânone colonial: ensaio. Brasília: Editora Universidade de Brasília, 1997.

LAFETÁ, João Luiz. Traduzir-se: ensaio sobre a poesia de Ferreira Gullar. In: LAFETÁ, João Luiz. A dimensão da noite e outros ensaios. Org. de Antonio Arnoni Prado. São Paulo: Duas Cidades; Ed. 34, 2014. P.114-212.

MOISÉS, Massaud. História da literatura brasileira: origens, barroco, arcadismo. São Paulo: Cultrix; Ed. da Universidade de São Paulo, 1983. v. I. MOSER, Benjamin. Autoimperialismo: três ensaios sobre o Brasil. Trad. de Eduardo Heck de Sá. São Paulo: Planeta, 2016.

PRADO JR., Caio. Formação do Brasil contemporâneo. 19. ed. São Paulo: Brasiliense, 1986.

ROCHA PITA, Sebastião da. História da América portuguesa. Brasília: Senado Federal, 2011) (Edições do Senado Federal, 157).

RONCARI, Luiz. Literatura brasileira:dos primeiros cronistas aos últimos românticos. 2. ed. São Paulo: Editora da Universidade de São Paulo; 
Fundação para o Desenvolvimento da Educação, 1995. (Didática; 2).

SAKATE, Marcelo. A conta era para todos. Veja, $\mathrm{n}^{\circ} 2.523,29$ mar. 2017, p. 66.

SCHWARCZ, Lilia M.; STARLING, Heloisa M. Brasil: uma biografia. São Paulo:

Companhia das Letras, 2015.

SOUZA, Jessé. A tolice da inteligência brasileira: ou como o país se deixa manipular pela elite. São Paulo: LeYa, 2015. 